\title{
STL Decomposition and SARIMA Model: The Case for Estimating Value-at-Risk of Covid-19 Increment Rate in DKI Jakarta
}

\author{
Agnes Zahrani ${ }^{1 *}$, Aniq A. Rohmawati ${ }^{1}$, Siti Sa'adah ${ }^{1}$ \\ ${ }^{1}$ School of Computing, Telkom University \\ Jl. Telekomunikasi 1 Terusan Buah Batu, Bandung, Jawa Barat, Indonesia \\ *agneszahrani@student.telkomuniversity.ac.id
}

\begin{abstract}
Construction of linear time series models to capture complex and various anomalies dataset structure is still a challenge. Application of such a time series model include the daily number Covid-19 outbreak. Today, the world still works hard to tackle and control this outbreak concerning in the increased levels of spread and severity. We propose an efficient technique for developing upper prediction for extreme value of daily Covid-19 increment rate following Seasonal Trend Loess (STL) Decomposition and Seasonal Autoregressive Integrated Moving Average (SARIMA) model. In particular, our key idea is to estimate Value-at-Risk (VaR) as upper limit using Variance Covariance simulation by identifying seasonal, trend and noise based the linear combination STL-SARIMA framework. Our simulation studies indicate that VaR provide sharp and well prediction with a MAPE results of 0.15 for extreme value with zero penalty. Since a number of positive cases has resulted unprecedented volatility, estimating the extreme value of increment rates become a crucial matter to support information and maintain essential health services. The proposed approach is illustrated by an application to the daily Covid-19 DKI Jakarta dataset.
\end{abstract}

Keywords: Autoregressive, Covid-19, Extreme value, Variance Covariance, Seasonal, Value-at-Risk.

\section{INTRODUCTION}

$\mathbf{T}$ here is unpredictable how long the Covid-19 pandemic will discontinue. There are some important aspects that have been carried out from this pandemic, including the public's efforts to slow spread and researchers' work to observe more about the virus. From the beginning of the health crisis, particularly following the news of the first and second positive case in Indonesia due to the Covid-19 on March 2, 2020, it has shocked the public. Afterwards, the number of daily cases increase simultaneously in other regions in Indonesia until today [1]. As the largest capital and metropolitan district of Indonesia, the province that has contributed the most to positive cases of Covid-19 in Indonesia is DKI Jakarta. This can be justified due to the fact that the mobility of the people in DKI Jakarta is relatively massive compared to 34 other provinces. Until the end of January 2021, DKI Jakarta reported 269,718 total cases with the highest increment rate on March 21, 2020 , at $24.19 \%$ and always fluctuating every day [1]. The Indonesian government has taken a number of measures with hope of preventing the Covid-19 to massive spreading, one of which is by imposing large-scale social restrictions. Since the high volatility of daily increment rate of Covid-19 lately, estimating the extreme value of increment rate become a crucial matter to support information and maintain essential health services.

Received on 15 May 2021. Revised at 7 Jun 2021, Accepted at 29 Jun 2021, Publish online at 8 July 2021 
STL DECOMPOSITION AND SARIMA MODEL: THE CASE FOR ESTIMATING VALUE-AT-RISK OF COVID-19 INCREMENT RATE IN DKI JAKARTA

Measuring extreme values plays important role in assessing risk and uncertainty in a number of Covid-19 cases. One of the core techniques for estimating extreme value is the Value-at-Risk (VaR) approach, introduced by Philippe Jorion [2]. VaR is a statistical approach to measure riskiness of financial entities of assets [2]. It is defined as the maximum Covid-19 increment might happen over particular time horizon and pre-defined confidence level. Many extensions have been proposed related to VaR. Jorion, P (2006) propose the multivariate model to estimate VaR [2]. Rohmawati and Syuhada (2015) consider improved VaR and Expected Shortfall by modifying coverage probability [3]. Meanwhile, Rejeb et al, [4] showed that variance covariance is the most proper method in estimating VaR compared to other methods, such as Historical Simulation, Bootstrapping and Monte Carlo methods.

Another important focus of assessing extreme value is on modeling the observation. According to Rob and George [5], Seasonal Trend Loess (STL) Decomposition is a well-approach model to approximate observations by identifying seasonal, trend and noise structures based on their advantages over other time series decomposition models, such as Classical Decomposition, SEATS Decomposition and X11 Decomposition. It is generally accepted that forecasting of time series observation is involving temporal dimension. Seasonal Autoregressive Moving Average (SARIMA) is one of the observation models that can be used to forecast time series. Dila Mulya, et al. [6] have compared forecasting the development of foreign tourists who come to Indonesia using the Holt Winter and SARIMA models with the results obtained that the SARIMA model is the best model. On the other hand, Shivam Bang, et al. [7] also compared the performance of the ARMA, ARMAX, and SARIMA models to predict rainfall and temperature in India, they found that the temperature is best predicted by the SARIMA model.

Thus, we consider to apply SARIMA for modelling seasonal pattern in STL Decomposition by estimating VaR. Detailed reviews of SARIMA and STL model can be found in Johannes Buhl, et al. and also Haritsah [8] [9]. The method used by [4] shall be developed with our research using the variance covariance method to estimate $\mathrm{VaR}$, would be explained further in state-of-the-art in section IV. This paper is organized in the following manner: in Section II, the framework of the model and VaR is introduced. VaR using Variance Covariance simulation and parameters of STL and SARIMA is revealed. In Section III, detailed procedure estimating VaR STL-SARIMA is presented to the real data of Covid-19 increment rate DKI Jakarta. In Section $\mathrm{IV}$, a comparison result $\mathrm{VaR}$ according to the confidence level is also reported. Finally, Section $\mathrm{V}$ conclusions made within the summary.

\section{LITERATURE REVIEW}

\section{A. Covid-19}

Coronavirus Disease-2019 (Covid-19), which is caused by the Severe Acute Respiratory Syndrome Coronavirus 2 (SARS-COV2) virus. This Covid-19 disease can cause symptoms such as fever, feeling tired, coughing, sneezing and runny. Covid-19 can be transmitted through droplets (droplets of liquid) from the nose or mouth that spread when the Covid-19 virus carrier coughs, sneezes, or is runny [1]. Starting from the first and second positive cases of Covid- 19 in Indonesia, there has been an increase in new cases of Covid-19 in Indonesia every day. The unpredictable rate of increase in number makes subscribers such as providing services, facilities, and medical personnel unpredictable. Various efforts were made to reduce the increase in new cases of Covid-19 in Indonesia, such as the government which imposed Large-Scale Social Restrictions, issued various health regulations and protocols, 3M campaigns (wearing masks, keeping your distance, and washing your hands regularly), the ban on Eid homecoming, and the disclosure of information on Covid-19 data in order to increase the awareness of the Indonesian people. There are several providers of Covid-19 data information in Indonesia that can be obtained by the public in the form of statistics, such kawalcovid19.id. The statistical variables for Covid-19 data that are commonly conveyed include the total number of cases, the number of new cases / daily, the number of active cases, the number of deaths, the number of cured cases, and also the number of increment rates. 


\section{B. Value-at-Risk (VaR)}

Measuring extreme values plays important role in assessing risk and uncertainty in a number of Covid-19 cases. One of the core techniques for estimating extreme value is the Value-at-Risk (VaR) approach, introduced by Philippe Jorion [2]. VaR is a statistical approach to measure riskiness of financial entities of assets [2]. It is defined as the maximum value expected to be happened over particular time horizon and pre-defined confidence level $(\alpha)$. Suppose $\operatorname{VaR}_{t}$ present Value-at-Risk at time $t$. VaR using Variance Covariance simulation can be described as follows [10],

$$
\operatorname{VaR}_{t}=\mu+k * \sigma
$$

$\mu$ presents mean of observed values, $k$ is the quantile (inverse of standard normal distribution with the desired $\alpha$ ), and $\sigma$ is the standard deviation derived from the STL- SARIMA model. The $\alpha$ states how big the probability that the VaR value will not exceed the maximum loss. The $\alpha$ determination plays an important role in measuring risk estimation, because it can illustrate how much an industry or company is able to take a risk that exceeds VaR. The greater the $1-\alpha$ that is taken, the greater the risk to be taken. A particular value $\alpha$ is $90 \%$, 95\%, or $99 \%$.

\section{Penalty of Value-at Risk (VaR)}

In calculating VaR estimation, there is a penalty for each violation. If the value at risk is smaller than the observed data in the daily time period, then there is violation. Thus, it is necessary to calculate the VaR penalty. The magnitude of penalty approximately equals to proposed $1-\alpha$.

$$
\text { Penalty of } \operatorname{VaR}=\frac{k}{n} \times 100 \%
$$

where, $k$ shows the number of VaR results that are less than the observed data, and $n$ is the number of observations.

\section{Seasonal Autoregressive Integrated Moving Average (SARIMA) Model}

In conducting a forecasting data, which contain seasonal elements, can consider Seasonal Integrated Autoregressive Moving Average (SARIMA). SARIMA is a developing model from the previous model for data that does not contain seasonality, ARIMA [11]. From several research to forecasting COVID-19 cases using the ARIMA model have been carried out with good modeling accuracy results [12] [13] [14]. ArunKumar, et al. used the ARIMA and SARIMA models for forecasting Covid-19 in 16 countries, then they found that the SARIMA model outperformed the ARIMA model in capture the seasonality or trends of the data [15]. So, it can be said that the SARIMA model is suitable to be applied in this research. The following is the equation of $\operatorname{SARIMA}(p, d, q)(\mathrm{P}, \mathrm{D}, \mathrm{Q})^{S}[6]$,

$$
\phi_{P} B^{S} \phi_{p}(\mathrm{~B})(1-B)^{d}\left(1-B^{S}\right)^{D} S_{t}=\theta_{q}(B) \theta_{q}\left(B^{S}\right) \varepsilon_{t}
$$

where,

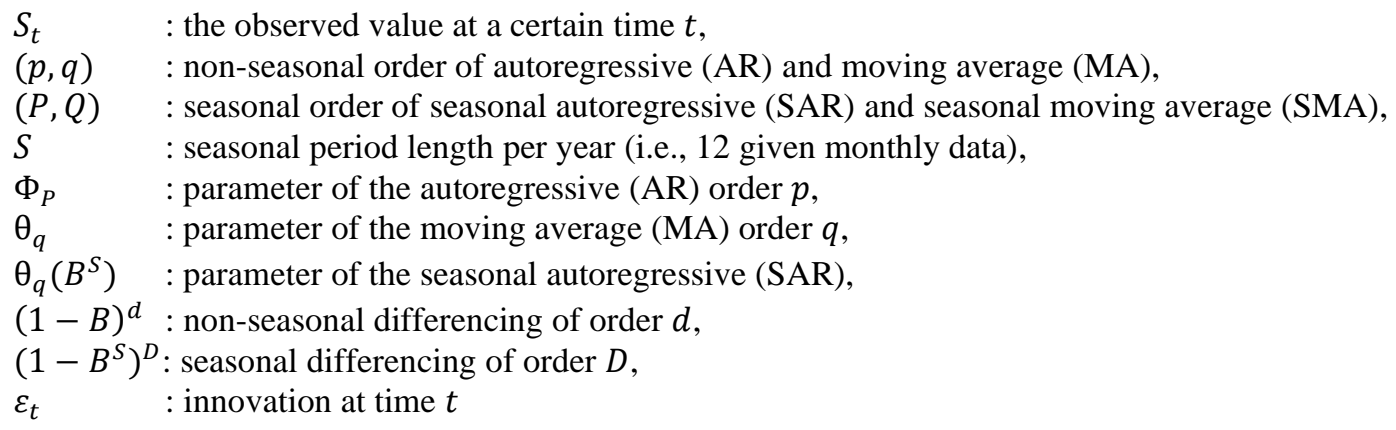


To find the optimal order of time series model sequence, we consider the minimum value of Akaike Information Criterion (AIC) [8].

$$
A I C=2 \log (L)+2(p+q+P+Q+k)
$$

Suppose $\delta$ represent as a parameter in the SARIMA, the parameter significance test on the SARIMA model can be carried out as follows [16]. We have hypothesis to determine the significance of parameters, $H_{0}: \delta=0$, the parameter is not significant to the model, and $H_{1}: \delta \neq 0$, the parameter is significant to the model. Define this following statistical test,

$$
t=\frac{\widehat{\delta}}{s . e(\delta)}
$$

If the $|t|>t_{(v, n-1)}$ or P-value $>\alpha$ with $v$ is a degree of freedom, then reject $H_{0}$.

\section{Seasonal Trend Loess (STL) Decomposition Model}

To identify the components that affect to the time series observation, it is necessary to decompose the dataset. One model that can be used is Seasonal Trend Loess (STL) Decomposition, it is a developed algorithm to decompose a time series observation into three components: trend, seasonal and noise [9]. The model developed by R. B. Cleveland, et al. In 1990 [17], has also used the Loess (Local Regression) method in refining or smoothing time series data, namely robust parameters. The STL Decomposition has four major parameters,

1. Period: the frequency parameter of the data.

2. Seasonal: long parameter for smoothing the seasonal component, must be an odd number.

3. Trend: long parameter for smoothing the trend component, must be an odd number and larger than the seasonal parameter.

4. Robust: parameter logical indication if a robust fitting is to be used in estimated Loess.

The mathematical equation of the STL Decomposition model based on the Additive model as follows.

$$
Y_{t}=S_{t}+T_{t}+R_{t}
$$

where, $Y_{t}$ is the observed time series value at time $t$ which is described as $S_{t}$ is the seasonal component at time $t$ following SARIMA model, $T_{t}$ is the trend-cycle component at time $t$, and $R_{t}$ is the residual component at time $t$.

\section{RESEARCh METHOD}

The flowchart design of VaR based STL-SARIMA model is described in Fig. 1. Through the design of this VaR estimation, which including data preparation, calculate the increment rate, splitting the training and testing data, Data analysis using STL Decomposition and forecasting increment rate of the daily number of new Covid19 cases based SARIMA using training dataset in DKI Jakarta. The selection of the best model is based on the smallest prediction error value. The error statistic used in determining this model is the Mean Absolute Percentage Error (MAPE). 


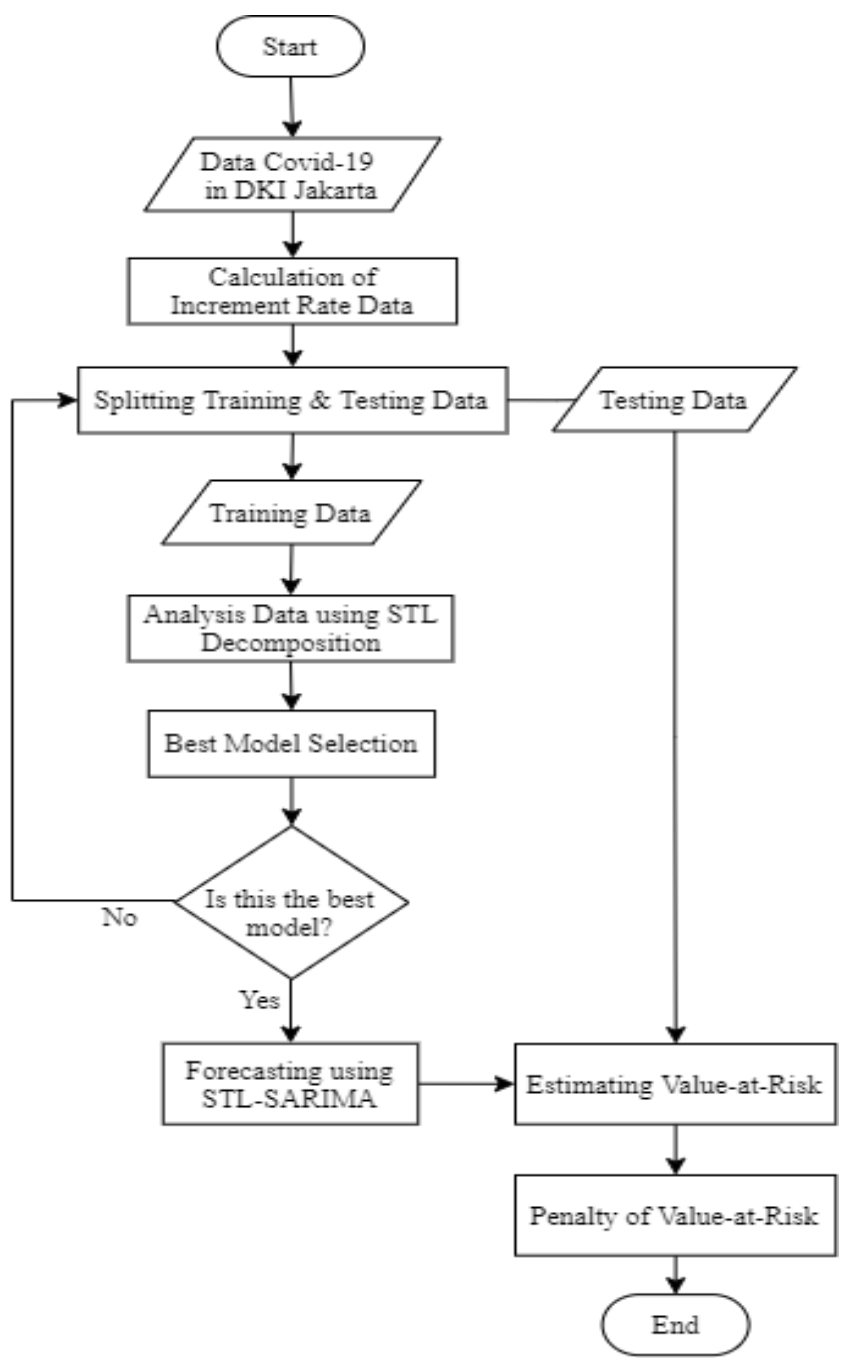

Fig. 1. Flowchart System of Value-at-Risk Estimation

\section{A. Calculation of Increment Rate Data}

The proposed dataset in this research is qualitative data about the Covid-19 cases in DKI Jakarta Province. This data is included in the time series data type obtained from the official website kawalcovid19.id. We consider the daily Covid-19 new cases and total cases in DKI Jakarta from May 1, 2020, to January 31, 2021 into STL-SARIMA model, the data shown in Table 1.

TABLE I

New CASES AND Total CASES Data OF COVID-19 in DKI JaKarta

\begin{tabular}{cccc}
\hline No. & Time Period (daily) & New Cases & Total Cases \\
\hline 1. & May 1, 2020 & 142 & 4317 \\
2. & May 2, 2020 & 80 & 4397 \\
3. & May 3, 2020 & 66 & 4463 \\
$\ldots$. & $\ldots$. & $\ldots$. & $\ldots$. \\
274. & January 29, 2021 & 3448 & 262753 \\
275. & January 30, 2021 & 3491 & 266244 \\
276. & January 31, 2021 & 3474 & 269718 \\
\hline
\end{tabular}


Then, the increment rate is calculated based on Table 1 with the following equation.

$$
i r_{t}=\frac{k_{t}}{t_{t}} \times 100 \%
$$

where $i r_{t}$ is defined as the percentage value of the increment rate of Covid-19 at a certain time period $t, k_{t}$ is the number of new Covid-19 cases at time $t, t_{t}$ is the total number of Covid-19 cases at time $t$.

TABLE II

INCREMENT RATE DATA OF COVID-19 CASES IN DKI JAKARTA

\begin{tabular}{ccc}
\hline No. & Time Period (daily) & Increment Rate \\
\hline 1. & May 1, 2020 & $3.29 \%$ \\
2. & May 2, 2020 & $1.82 \%$ \\
3. & May 3, 2020 & $1.48 \%$ \\
$\ldots$. & $\ldots .$. & $\ldots$. \\
274. & January 29, 2021 & $1.31 \%$ \\
275. & January 30, 2021 & $1.31 \%$ \\
276. & January 31, 2021 & $1.29 \%$ \\
\hline
\end{tabular}

\section{B. Split Training and Testing Data}

We provide training data to construct the STL-SARIMA model, considering the Rainfall Forecasting research [18] which proved that the larger the training data, the better results obtained. Thus, we split dataset into $90 \%$ for training, and $10 \%$ to test performance of the proposed model as can be seen in Fig.2. Thus, we have 240 time series observation which involve in STL-SARIMA process. Afterwards, we apply parameters estimation of STL-SARIMA to Variance Covariance simulation.

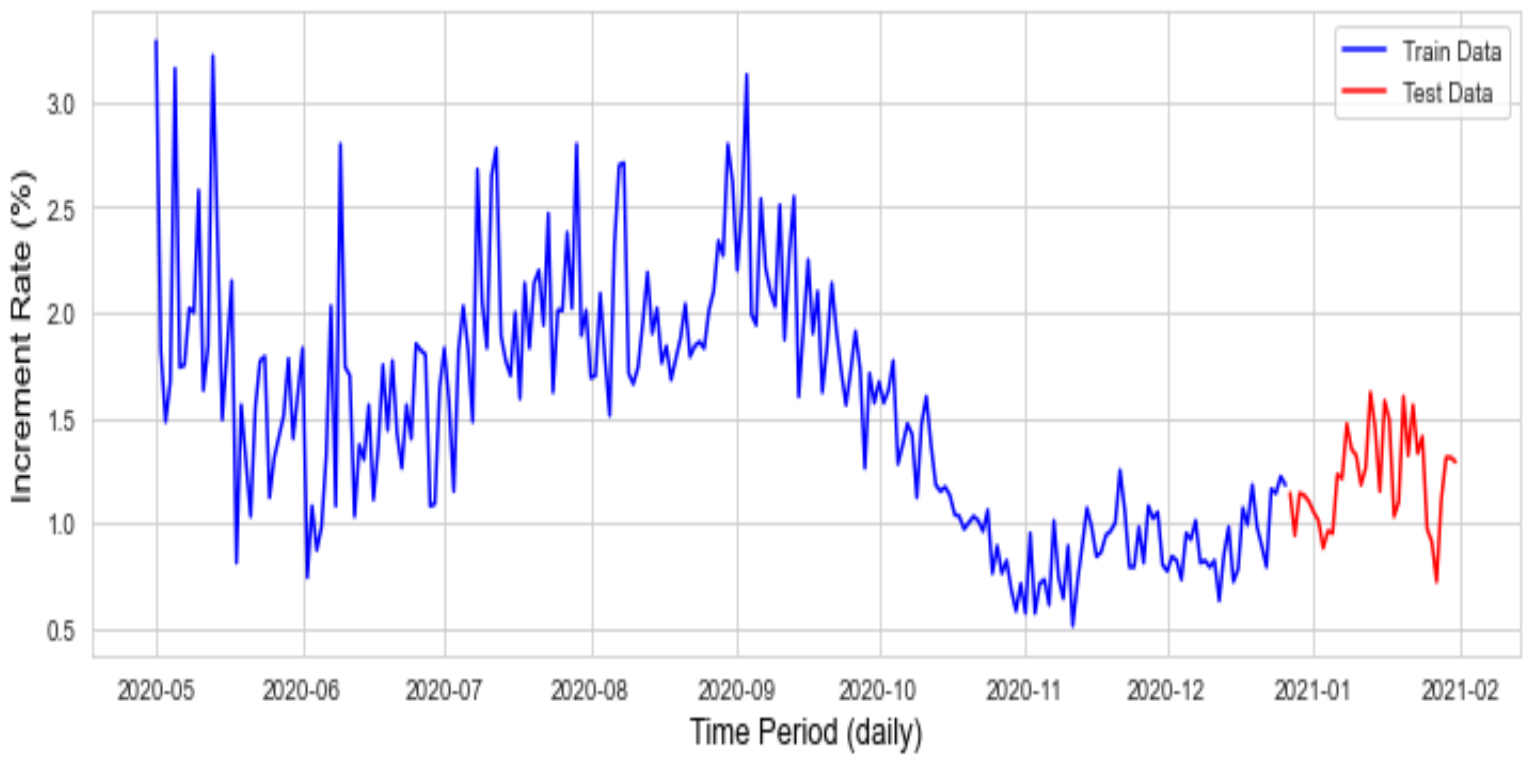

Fig. 2. Graph of Training and Testing Data 


\section{STL Decomposition Model}

The STL Decomposition will decompose the training dataset into three components: trend, seasonal and noise.

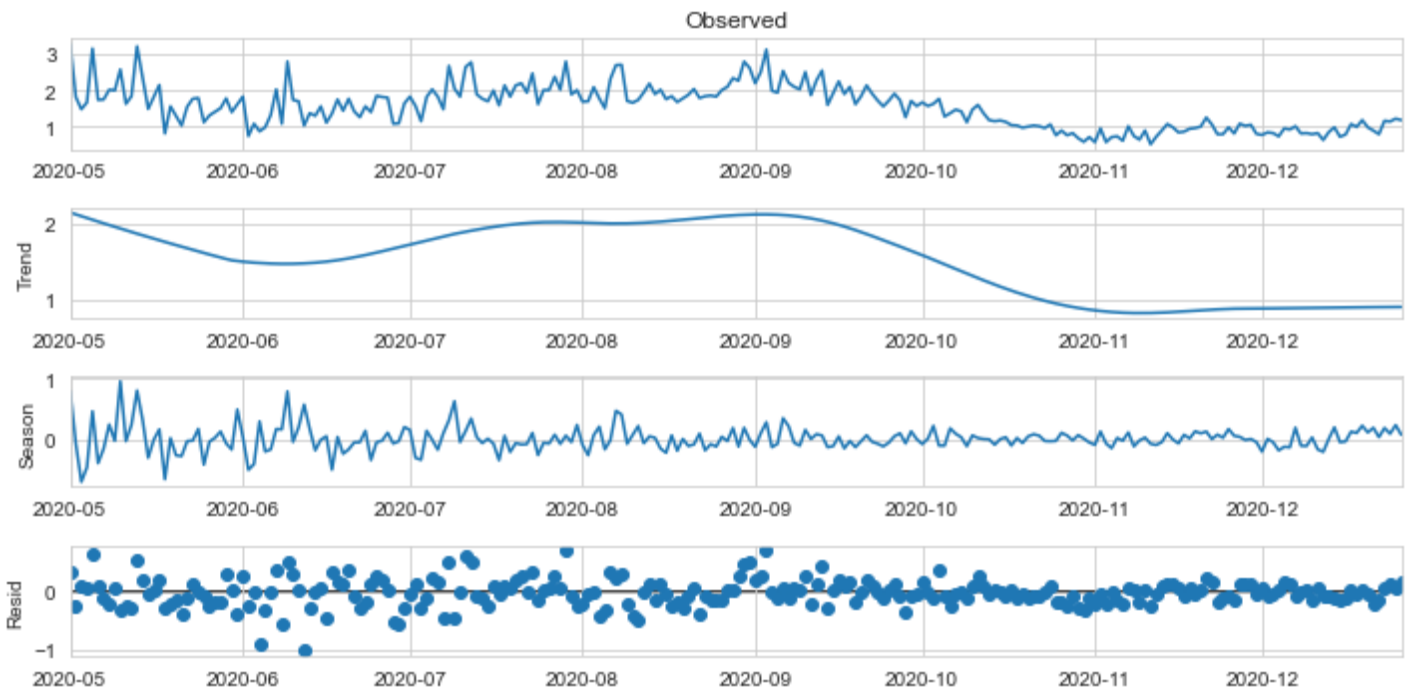

Fig. 3. STL Decomposition of the Covid-19 Increment Rate in DKI Jakarta

According to Fig. 3, STL Decomposition provides trend characteristics of the Covid-19 increment rate in DKI Jakarta. The first plot shows the observed values, the second represents the trend component, the third subgraph reveals the seasonal component, and the last subgraph shows the residual component. Beside trend and noise components, the dataset also reveals a significant seasonal pattern. Because we have the observed value is time series data, we apply SARIMA model to capture seasonality over the dataset.

\section{SARIMA Model}

It is necessary to select the order of SARIMA model, to choose order $(p, d, q)(\mathrm{P}, \mathrm{D}, \mathrm{Q})^{S}$, we consider to identify based on the minimum AIC and statistical test of proposed parameters. The SARIMA $(0,1,2)(2,1,0)^{12}$ shown minimum AIC based Equation 4, 257.794. Moreover, the statistical test according to Equation 5, each parameters reveals a significant contributionto the $\operatorname{SARIMA}(0,1,2)(2,1,0)^{12}$ model, the value of $p>|z|$ of these parameters is less than $5 \%$.

TABLE III

PARAmeter Estimation of Best Model SARIMA $(0,1,2)(2,1,0)^{12}$

\begin{tabular}{ccccc}
\hline Parameters & $\boldsymbol{c o e} \boldsymbol{f}$ & $\boldsymbol{z}$ & $\boldsymbol{p}>|\mathbf{z}|$ & Significance Test \\
\hline $\boldsymbol{x} \mathbf{1}$ & -0.0052 & -0.832 & 0.005 & Significant \\
$\boldsymbol{m a} \boldsymbol{.} \boldsymbol{L} \mathbf{1}$ & -0.0661 & -13.059 & 0.000 & Significant \\
$\boldsymbol{m a} \boldsymbol{L} \mathbf{L}$ & -0.1133 & -2.217 & 0.027 & Significant \\
\hline $\boldsymbol{s i g m a 2}$ & 0.1175 & 20.342 & 0.000 & Significant \\
\hline
\end{tabular}

\section{E. VaR Based STL-SARIMA Model}

According to the result of AIC, the optimal order of SARIMA model with the lowest AIC is $(0,1,2)(2,1,0)^{12}$. Thus, $S_{t}$ as seasonal of STL Decomposition can be written as follows, 
STL DECOMPOSITION AND SARIMA MODEL: THE CASE FOR ESTIMATING VALUE-AT-RISK OF COVID-19 INCREMENT RATE IN DKI JAKARTA

$$
(1-B)\left(1-B^{12}\right)\left(1-\Phi_{1} B^{12}-\Phi_{2} B^{24}\right) S_{t}=\left(1+\theta_{1} B+\theta_{2} B^{2}\right) \epsilon_{t}
$$

Thus, we can construct STL-SARIMA model in Equation 8. We estimate VaR by running Variance Covariance simulation in Equation 1 based parameters and forecasting result of STL-SARIMA model.

\section{RESULTS AND DISCUSSION}

The forecasting performance of the STL-SARIMA model considering training and testing data (90:10), of the Covid-19 increment rate in DKI Jakarta dataset, reveals well-performed with Mean Absolute Percentage Error (MAPE) 0.15. According to forecasting performance, we estimate $\mathrm{VaR}$ using three different $\alpha$ : $90 \%$, 95\%, and 99\%. The results of the VaR estimation are shown in Table IV.

TABLE IV

VAR ESTIMATION BASED ON STL-SARIMA PROCESS

\begin{tabular}{|c|c|c|c|c|c|}
\hline \multirow{2}{*}{$\begin{array}{l}\text { Time Period } \\
\text { (daily) }\end{array}$} & \multirow{2}{*}{$\begin{array}{l}\text { Observed } \\
\text { Data }\end{array}$} & \multirow{2}{*}{$\begin{array}{l}\text { Forecasting } \\
\text { Data }\end{array}$} & \multicolumn{3}{|c|}{ VaR } \\
\hline & & & $90 \%$ & $95 \%$ & $99 \%$ \\
\hline December 27, 2020 & 1.14 & 1.18 & 1.98 & 2.10 & 2.34 \\
\hline December 28,2020 & 0.94 & 1.11 & 1.98 & 2.10 & 2.34 \\
\hline December 29, 2020 & 1.14 & 0.93 & 1.98 & 2.10 & 2.33 \\
\hline December 30, 2020 & 1.13 & 1.14 & 1.97 & 2.10 & 2.33 \\
\hline December 31, 2020 & 1.1 & 1.19 & 1.97 & 2.10 & 2.33 \\
\hline January 1, 2020 & 1.05 & 1.15 & 1.97 & 2.09 & 2.33 \\
\hline January 2,2020 & 1.01 & 1.07 & 1.97 & 2.09 & 2.33 \\
\hline January 3, 2020 & 0.88 & 1.09 & 1.97 & 2.09 & 2.32 \\
\hline January 4, 2020 & 0.96 & 0.94 & 1.96 & 2.09 & 2.32 \\
\hline January 5, 2020 & 0.95 & 0.92 & 1.96 & 2.09 & 2.32 \\
\hline January 6,2020 & 1.23 & 0.94 & 1.96 & 2.08 & 2.32 \\
\hline January 7,2020 & 1.21 & 1.28 & 1.96 & 2.08 & 2.32 \\
\hline January 8,2020 & 1.47 & 1.24 & 1.96 & 2.08 & 2.31 \\
\hline January 9, 2020 & 1.35 & 1.49 & 1.96 & 2.08 & 2.31 \\
\hline January 10,2020 & 1.32 & 1.31 & 1.96 & 2.08 & 2.31 \\
\hline January 11,2020 & 1.18 & 1.29 & 1.96 & 2.08 & 2.31 \\
\hline January 12,2020 & 1.26 & 1.20 & 1.95 & 2.08 & 2.31 \\
\hline January 13,2020 & 1.62 & 1.31 & 1.95 & 2.08 & 2.31 \\
\hline January 14, 2020 & 1.45 & 1.65 & 1.95 & 2.08 & 2.31 \\
\hline January 15,2020 & 1.15 & 1.47 & 1.95 & 2.08 & 2.31 \\
\hline January 16,2020 & 1.58 & 1.15 & 1.95 & 2.08 & 2.31 \\
\hline January 17, 2020 & 1.49 & 1.68 & 1.95 & 2.08 & 2.31 \\
\hline January 18,2020 & 1.03 & 1.55 & 1.95 & 2.08 & 2.31 \\
\hline January 19, 2020 & 1.1 & 1.01 & 1.95 & 2.07 & 2.31 \\
\hline January 20, 2020 & 1.6 & 1.07 & 1.95 & 2.07 & 2.31 \\
\hline January 21,2020 & 1.32 & 1.57 & 1.95 & 2.07 & 2.31 \\
\hline January 22, 2020 & 1.56 & 1.30 & 1.95 & 2.07 & 2.31 \\
\hline January 23, 2020 & 1.33 & 1.59 & 1.95 & 2.07 & 2.31 \\
\hline January 24, 2020 & 1.41 & 1.35 & 1.95 & 2.07 & 2.31 \\
\hline January 25, 2020 & 0.97 & 1.45 & 1.95 & 2.07 & 2.31 \\
\hline January 26, 2020 & 0.91 & 0.99 & 1.95 & 2.07 & 2.30 \\
\hline January 27, 2020 & 0.72 & 0.99 & 1.94 & 2.07 & 2.30 \\
\hline January 28,2020 & 1.11 & 0.76 & 1.94 & 2.06 & 2.30 \\
\hline January 29, 2020 & 1.31 & 1.11 & 1.94 & 2.06 & 2.30 \\
\hline January 30, 2020 & 1.31 & 1.36 & 1.94 & 2.06 & 2.30 \\
\hline January 31,2020 & 1.29 & 1.37 & 1.94 & 2.06 & 2.30 \\
\hline
\end{tabular}

Our state-of-the-art VaR method by using STL-SARIMA model as a support to estimate the data we use, compared to the previous research [4], VaR is used without any parameters of the model. VaR that being used on this research is Variance Covariance method that can build time series data research forecasting using STL- 
SARIMA model parameter. VaR that we build has never been used for estimating the rate of VaR on STLSARIMA combination model in another research. As for the results obtained, they are well enough on the first time VaR model building which involves STL-SARIMA parameter.

Following the result in Table IV, it presents that $\mathrm{VaR}$ with $\alpha-99 \%$ has a greater result than VaR with $\alpha-$ $90 \%$ and $\alpha-95 \%$. Specifically, look at the VaR estimation results on December 27, 2020. The VaR estimation using $\alpha-90 \%$ obtained VaR of 1.98 . This means that there is $90 \%$ confidence that the value of the Covid-19 Increment Rate in DKI Jakarta will not exceed $1.98 \%$ in the next one-day period. Then, VaR estimation using $\alpha-95 \%$ obtained $\mathrm{VaR}$ of 2.10 . This means that there is a $95 \%$ confidence that the value of the Covid-19 Increment Rate in DKI Jakarta will not exceed $2.10 \%$ in the next one-day period. Meanwhile, VaR estimation using $\alpha-99 \%$ obtained VaR of 2.34 . This means that there is $99 \%$ confidence that the value of the Covid-19 Increment Rate in DKI Jakarta will not exceed $2.34 \%$ in the next one-day period. From the results of the VaR estimation, it is necessary to evaluate penalty of this VaR estimation. The VaR's violation can be assessed by Equation 2. The results show that there is zero violation of VaR estimation in $\alpha: 90 \%, 95 \%$, and $99 \%$.

\section{CONCLUSION}

The daily data of new cases Covid-19 reported fluctuations, several seasonal and noise patterns also captured lately. As the massive severity of the virus, identifying the future number of increment rates become a major concern to support information and maintain essential health services. Measuring extreme values plays important role in assessing risk and uncertainty in a number of Covid-19 cases. Value-at-Risk (VaR) is defined as the maximum Covid-19 increment rate expected to be happened over particular time horizon and pre-defined confidence level. The Seasonal Trend Loess (STL) Decomposition is a well-approach to approximate observation by identifying seasonal, trend and noise structure. It generally accepted that forecasting of time series observation is involving temporal dimension. Thus, we consider to apply Seasonal Autoregressive Moving Average (SARIMA) for modelling seasonal pattern in STL Decomposition. The $\operatorname{SARIMA}(0,1,2)(2,1,0)^{12}$ shown a significant parameter and minimum AIC, 257.794. The VaR using Variance Covariance simulation by identifying seasonal, trend and noise based the linear combination STLSARIMA framework which a MAPE results of 0.15 provides sharp and well prediction for extreme value with zero penalty. According to VaR estimation, it shown that the higher the level of confidence, then the greater the risk that possible to be borne. Suppose we estimate VaR at $99 \%$ confidence level, thus, government and public health services should consider by the rule that the daily $99 \%$ extreme value of the Covid-19 increment rates should not exceed a VaR estimation. Therefore, under the high volatility of increment rate of this outbreak, finding an appropriate model to estimate upper prediction, such assessing VaR involving its coverage probability and heteroscedastic time series process, is desirable and should be considered.

\section{REFERENCES}

[1] Tim Relawan KawalCOVID-19, "Grafik Interaktif untuk Data per Provinsi," Indika Foundation, 1 March 2020. [Online]. Available: https://kawalcovid19.id/. [Accessed 15 April 2021].

[2] P. Jorion, Value at Risk : The New Benchmark for Managing Financial Risk, Second Edition, New York: The McGraw-Hill Companies, Inc, 2002.

[3] A. A. Rohmawati and K. Syuhada, "Value-at-Risk and Expected Shortfall Relationship," International Journal of Applied Mathematics and Statistics, vol. 53, no. 5, pp. 211-215, October 2015.

[4] A. B. Rejeb, O. B. Salha and J. B. Rejeb, "Value-at-Risk Analysis for the Tunisian Currency Market: A Comparative Study," International Journal of Economics and Financial Issues, vol. 2, no. 2, pp. 110$125,2012$. 
STL DECOMPOSITION AND SARIMA MODEL: THE CASE FOR ESTIMATING VALUE-AT-RISK OF COVID-19 INCREMENT RATE IN DKI JAKARTA

[5] R. J. Hyndman and G. Athanasopoulos, Forecasting: Principles and Practice, 2nd ed., Melbourne: OTexts, 2018.

[6] D. Mulya, Y. Asdi and F. Yanuar, "Penerapan Metode Holt Winter dan Seasonal ARIMA Pada Peramalan Perkembangan Wisatawan Mancanegara Yang Datang ke Indonesia," Jurnal Matematika UNAND, vol. VI, pp. 29-36, 2017.

[7] S. Bang, R. Bishnoi, A. S. Chauhan, A. K. Dixit and I. Chawla, "Fuzzy Logic based Crop Yield Prediction using Temperature and Rainfall parameters predicted through ARMA, SARIMA, and ARMAX models," 2019 Twelfth International Conference on Contemporary Computing (IC3), pp. 1-6, 19 September 2019.

[8] J. Buhl, C. Liedtke, S. Schuster and K. Bienge, "Predicting the Material Footprint in Germany between 2015 and 2020 via Seasonally Decomposed Autoregressive and Exponential Smoothing Algorithms," Resources 2020, vol. 9, p. 125, 25 October 2020.

[9] A. Haritsah, Implementasi Model STL Seasonal Trend Decomposition Based On Loess dan ARIMA Untuk Prediksi Konsentrasi Kualitas Udara, Surabaya: Institut Teknologi Sepuluh November, 2015.

[10] D. A. I. Muruddani and A. Purbowati, "Pengukuran Value At Risk Pada Aset Tunggal dan Portofolio Dengan Simulasi Monte Carlo," Media Statistika, vol. 2, pp. 93-104, December 2009.

[11] P. Utomo and A. Fanani, "Peramalan Jumlah Penumpang Kereta Api di Indonesia Menggunakan Metode Seasonal Autoregressive Integrated Moving Average (SARIMA)," Jurnal Mahasiswa Matematika ALGEBRA, vol. 1, pp. 169-178, 2020.

[12] H. Wiguna, Y. Nugraha, F. R. R., A. Andika, J. I. Kanggarawan and A. L. Suherman, "Kebijakan Berbasis Data: Analisis dan Prediksi Penyebaran COVID-19 di Jakarta dengan Metode Autoregressive Integrated Moving Average (ARIMA)," Jurnal Sistem Cerdas, vol. 03, no. 02, pp. 74-83, 2020.

[13] A. K. Rachmawati and S. D. Miasary, "Peramalan Penyebaran Jumlah Kasus Virus Covid-19 Provinsi Jawa Tengah dengan Metode Arima," Zeta - Math Journal, vol. 6, no. 1, May 2021.

[14] Supriatun, I. Solihati, P. R. Arum and T. T. W. Utami, "Peramalan Jumlah Kasus Covid-19 di Semarang Menggunakan Metode Autoregressive Integrated Moving Average," Prosiding Seminar Edusainstech, vol. 4, 2020.

[15] K. E. ArunKumar, D. V. Kalaga, C. M. S. Kumar, G. Chilkoor, M. Kawaji and T. M. Brenza, "Forecasting the dynamics of cumulative COVID-19 cases (confirmed, recovered and deaths) for top-16 countries using statistical machine learning models: ARIMA and SARIMA," Appl Soft Comput., vol. 103, no. 107161, May 2021.

[16] J. E. Hanke and D. W. Wichern, Business Forecasting, 8th Edition, New York: New Jersey: Pearson, Prentice Hall, 2005.

[17] R. B. Cleveland, W. S. Cleveland, J. E. McRae and I. Terpenning, "STL: A Seasonal-Trend Decomposition Procedure Based on Loess," Jurnal of Official Statistics, vol. 6, pp. 3-73, 1990.

[18] A. B. Wijaya, C. Dewi and B. Rahayudi, "Peramalan Curah Hujan Menggunakan Metode High Order Fuzzy Time Series Multi Factors," Jurnal Pengembangan Teknologi Informasi dan Ilmu Komputer, vol. 2, no. 3, pp. 930-939, March 2018. 